\title{
Designation of the Neotype Strain of Bacteroides hypermegas Harrison and Hansen
}

\author{
ELIZABETH P. CATO AND ELLA M. BARNES \\ Anaerobe Laboratory, Division of Basic Sciences, College of Agriculture and Life Sciences, Virginia \\ Polytechnic Institute and State University, Blacksburg, Virginia 24061, and Agricultural Research Council, \\ Food Research Institute, Colney Lane, Norwich, NR4 7UA, England
}

When Harrison and Hansen first described and named Bacteroides hypermegas in 1963, they did not designate a type strain for the species. All of the original isolates have been lost, but a strain with characteristics that agree closely with those reported by Harrison and Hansen has been deposited as a reference strain in the ATCC and the NCTC. This strain, ATCC 25560 (= NCTC 10570), is here described and is designated the neotype strain of Bacteriodes hypermegas Harrison and Hansen.

In 1963, Harrison and Hansen (7) described a new species of Bacteroides, three strains of which they had isolated in 1950 from the feces of turkeys. They proposed the name Bacteroides hypermegas for the species but did not designate a type strain. Stevens had included two of these strains, received from A. P. Harrison, in studies for his $\mathrm{Ph}$.D. thesis (Vanderbilt University, Nashville, Tenn., 1956). He named the strains Bacteroides saucissus. Since this designation was proposed in a thesis, not published for general distribution, the name is not considered to be validly published (Rule 25a, Bacteriological Code [11]).

The original isolates of Harrison and Hansen, as well as the cultures which Stevens studied, have been lost. However, strains isolated from cecal contents of chickens by Barnes and Goldberg (1), and first reported in 1962, were later found to have characteristics, both morphological and biochemical, that agreed closely with those described by Harrison and Hansen for $B$. hypermegas (2-7). One of these strains, EB/F/61/42, was deposited by L. V. Holdeman in the American Type Culture Collection, Rockville, Md., as a reference strain of $B$. $h y$ permegas (9). This strain was also deposited by E. M. Barnes in the National Collection of Type Cultures as NCTC 10570 and is listed in their catalog as the neotype strain. However, no formal designation of this strain as neotype was published. The purpose of this paper is to designate a neotype strain for $B$. hypermegas according to the Rules of the Bacteriological Code.

\section{MATERIALS AND METHODS}

The characteristics and reactions of $B$. hypermegas ATCC 25560 were determined using anaerobic techniques and prereduced media as described in the Virginia Polytechnic Institute Anaerobe Laboratory
Manual (10). The basal broth medium contained $0.5 \%$ peptone (Difco), $0.5 \%$ Trypticase (BBL), $0.5 \%$ yeast extract, $0.5 \mathrm{mg} \%$ hemin, $17 \mu \mathrm{l} \%$ vitamin $\mathrm{K}_{1}$, salts, cysteine-hydrochloride, and resazurin (10). Tubes were inoculated under oxygen-free $\mathrm{CO}_{2}$ and incubated at $37^{\circ} \mathrm{C}$. Blood agar plates were freshly prepared on the day of use from brain heart infusion agar with $0.5 \%$ yeast extract, $0.5 \mathrm{mg} \%$ hemin, 100 $\mu 1 \%$ vitamin $K_{1}$, and $5 \%$ defibrinated sheep blood added. Inoculated plates were incubated in GasPak (BBL) jars using 90\% hydrogen-10\% $\mathrm{CO}_{2}$ for the gaseous phase. Antibiotic susceptibility was determined by the method of Wilkins and Thiel (16).

Methods used in characterizing this strain were previously described $(8,10,15)$.

\section{RESULTS AND DISCUSSION}

The cells of $B$. hypermegas ATCC 25560 are distinctive in morphology and are just as described in the original publication on $B$. hypermegas (7). They are large ( $3.0 \mu \mathrm{m}$ wide by 4.6 to $11.6 \mu \mathrm{m}$ long), gram-negative rods with rounded ends, usually granular in appearance (Fig. 1).

The organism is strictly anaerobic and nonmotile. It does not form spores or survive heating at $80^{\circ} \mathrm{C}$ for $10 \mathrm{~min}$. The optimum temperature for growth is $37^{\circ} \mathrm{C}$, although it grows nearly as well at $45^{\circ} \mathrm{C}$. There is no growth in 24 $h$ at 25 or $30^{\circ} \mathrm{C}$.

Surface colonies on anaerobic blood agar plates, after incubation for 2 days, are 4 to 5 $\mathrm{mm}$ in diameter, circular, entire, flat to convex, semiopaque, granular or mottled, gray-white, and nonhemolytic.

Glucose broth cultures are turbid with a smooth or flocculent sediment. Final pH after 5 days of incubation at $37^{\circ} \mathrm{C}$ is 4.8 .

Reactions of this strain after 5 days of incubation and reactions of the species as reported by Harrison and Hansen (7) are listed in Table 1. 


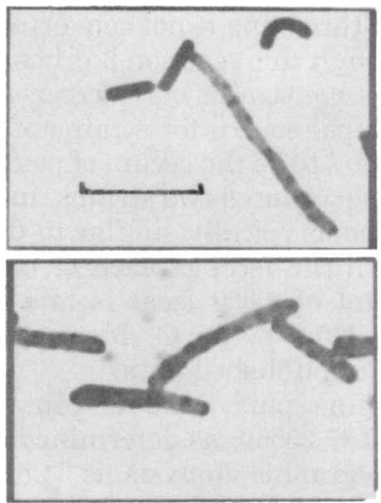

Fig. 1. Light micrograph of $B$. hypermegas ATCC 25560. (Top) cells from 24-h-old PY broth culture; (bottom) cells from 24-h-old PY-glucose broth culture. Bar represents $10 \mu \mathrm{m}$.

Harrison and Hansen stated that gas was not formed in carbohydrate cultures (7), and Goldberg et al. reported that "copious" gas was not produced (6). However, we observed significant amounts of gas in glucose agar deep cultures both from ATCC 25560 and from five other strains we examined. Hydrogen gas was not formed as determined chromatographically by the method described by Moore and Holdeman (15), but more $\mathrm{CO}_{2}$ was detected in the head space above fructose broth cultures that had been inoculated under oxygen-free nitrogen than was found in uninoculated control fructose tubes similarly flushed with $\mathrm{N}_{2}$. Since Harrison and Hansen determined gas production using soft Vaseline seals rather than 2\% agar deeps, the $\mathrm{CO}_{2}$ produced from the fermentation of glucose may have escaped. This could account for much of the fermented glucose Harrison and Hansen were unable to identify in products formed.

Harrison and Hansen (7) reported that the ratio of acetic and propionic acids and "nonvolatile acid calculated as lactic acid" produced from the fermentation of glucose after 2 weeks of incubation was approximately 3:5:9 at $\mathrm{pH}$ 4.5. Under our conditions, products determined by gas-liquid chromatography (10) of a 5-dayold glucose broth culture of ATCC 25560 (final $\mathrm{pH}, 4.8$ ) were: propionic acid, 7.8 milliequivalents (meq) $/ 100 \mathrm{ml}$; acetic acid, $0.8 \mathrm{meq} / 100 \mathrm{ml}$; and traces of lactic acid. Among some other anaerobes, the relative proportion of shortchain fatty-acid end products has been shown to be sensitive to medium components and to length of incubation (13). Also, the amount of lactic acid produced in combination with other acids may be sensitive to the hemin content of
Table 1. Reactions of Bacteroides bypermegas $a$

\begin{tabular}{|c|c|c|}
\hline Reaction & $\begin{array}{l}\text { Harrison } \\
\text { and } \\
\text { Hansen (7) }\end{array}$ & $\begin{array}{l}\text { ATCC } \\
25560\end{array}$ \\
\hline Nitrate reduced & - & - \\
\hline Catalase produced & - & - \\
\hline $\mathrm{H}_{2} \mathrm{~S}$ produced & - & trace \\
\hline Gas produced & - & $4+$ \\
\hline Susceptibility to penicillin & in + & + \\
\hline Growth in $6.5 \% \mathrm{NaCl}$ & - & - \\
\hline \multicolumn{3}{|l|}{ Acid from: } \\
\hline Arabinose & + & + \\
\hline Cellobiose & + & + \\
\hline Dextrin & w & - \\
\hline Fructose & + & + \\
\hline Galactose & + & + \\
\hline Glucose & + & + \\
\hline Glycerol & - & + \\
\hline Inositol & - & - \\
\hline Lactose & + & + \\
\hline Maltose & + & + \\
\hline Mannitol & + & + \\
\hline Mannose & + & + \\
\hline Melezitose & - & - \\
\hline Melibiose & + & + \\
\hline Raffinose & + & + \\
\hline Rhamnose & - & - \\
\hline Salicin & + & $\mathbf{w}$ \\
\hline Sorbitol & + & + \\
\hline Starch & - & - \\
\hline Trehalose & + & + \\
\hline Xylose & + & + \\
\hline Products detected $b$ & LPA & PAl \\
\hline
\end{tabular}

$a_{\text {Symbols: }}-$, negative reaction; + , positive reaction (carbohydrate cultures, $\mathrm{pH}$ below 5.5); $\mathrm{w}$, $\mathrm{pH}$ between 5.5 and 6.0 ; number (gas), amount estimated on "- to 4+" scale; L, lactic acid; $\mathrm{P}$, propionic acid; $\mathrm{A}$, acetic acid

$b_{\text {Products are listed in order of relative amounts }}$ detected. Small letters indicate trace amounts.

the medium (12; also M. D. Appleman, J. L. Johnson, and T. D. Wilkins, Abstr. Annu. Meet. Amer. Soc. Microbiol. 1976, I128, p. 132). Hemin and vitamin $K_{1}$ were not added to media 
TABLE 2. Fermentation products of $B$. hypermegas ATCC 25560

\begin{tabular}{lll}
\hline \multicolumn{1}{c}{ Product } & PYG $^{n}$ & PYG-HK \\
\hline Volatile acid & & \\
$\quad$ Acetic acid & $2.5^{b}$ & 2.1 \\
$\quad$ Propionic acid & 5.3 & 4.5 \\
Nonvolatile acid & & \\
$\quad$ Pyruvic acid & 0.9 & 0.3 \\
Lactic acid & 1.3 & 1.0 \\
Succinic acid & 1.6 & 0.4 \\
Total non volatile acids & 3.8 & 1.7 \\
\hline
\end{tabular}

${ }^{a}$ PYG, Peptone-yeast extract-glucose; PYG-HK, $P Y G+$ hemin and vitamin $K_{1}$.

${ }^{b}$ Products were determined by gas-liquid chromatography (10) and are recorded as milliequivalents per $100 \mathrm{ml}$ of culture.

used by Harrison and Hansen, and this might account for the greater amount of nonvolatile acid they observed. To test this hypothesis, ATCC 25560 was transferred serially three times in peptone-yeast extract-glucose broth without added vitamin $\mathrm{K}_{1}$ and hemin (PYG), and the third transfer was used to inoculate PYG and PYG with hemin and vitamin $\mathrm{K}_{1}$ added. Products of fermentation after incubation of these cultures for 5 days are shown in Table 2 . In addition to the acid products shown, ethyl alcohol was detected from both cultures. The concentration of lactic acid was not appreciably influenced by the hemin and vitamin $\mathrm{K}_{1}$ (Table 2), but the total amount of nonvolatile acids was significantly greater in the medium without hemin and vitamin $K_{1}$ because of the large amount of succinic acid that accumulated in the PYG culture. Also, because strains of this species convert lactate to propionate $(7.6$ meq of propionate per $100 \mathrm{ml}$ of $1 \%$ lactate broth culture as compared with $1.1 \mathrm{meq} / 100 \mathrm{ml}$ in basal peptone-yeast extract broth culture of ATCC 25560), it would be surprising to find a great accumulation of lactate in carbohydrate cultures.

The original isolates did not ferment glycerol, but Goldberg et al. (6) reported that, although glycerol was usually not fermented, acid might be formed after prolonged incubation. We found that a glycerol broth culture of ATCC 25560 after 5 days of incubation had a pH of 5.0. Glycerol was weakly fermented ( $\mathrm{pH} 5.9$ ) by one other strain tested and was not fermented by two others.

Additional reactions of ATCC 25560 that are in agreement with those reported for $B$. hypermegas by Goldberg et al. (6) and Barnes and Impey (3-5) are: gelatin is not liquefied; milk is not curdled; indole is not formed; bile is not stimulatory for growth; lecithinase is not formed; deoxyribonucleic acid (DNA) is not at- tacked; and threonine is not converted to propionate, although this reaction has been reported to occur in some strains of $B$. hypermegas (14).

The principal source for strains of $B$. hypermegas appears to be the cecum of poultry. However, we have isolated two strains, morphologically and phenotypically similar to the poultry strains, from the feces of each of two persons out of a total of 9,000 fecal isolates from 119 individuals (15; W. E. C. Moore and L. V. Holdeman, unpublished data).

The guanine plus cytosine content of the DNA of ATCC 25560 , as determined by Sebald by chromatographic analysis, is $34.8 \mathrm{~mol} \%$ (3).

The characteristics of ATCC 25560 (= NCTC 10570) agree closely with those given in the original description of $B$. hypermegas by Harrison and Hansen. This strain is therefore designated as the neotype strain of $B$. hypermegas Harrison and Hansen. Glycerol fermentation appears to be a variable characteristic within the species; gas production and the proportion of fatty acids produced from the fermentation of glucose are dependent on components of the media used for their determination.

\section{ACKNOWLEDGMENTS}

We thank Carolyn W. Salmon for excellent technical assistance.

This investigation was supported by Public Health Service Grant 14604 from the National Institute of General Medical Sciences.

\section{REPRINT REQUESTS}

Address reprint requests to: Elizabeth P. Cato, Anaerobe Laboratory, VPI \& SU, P.O. Box 49, Blacksburg, VA 24060.

\section{LITERATURE CITED}

1. Barnes, E. M., and H. S. Goldberg. 1962. The isolation of anaerobic gram-negative bacteria from poultry reared with and without antibiotic supplements. $J$ Appl. Bacteriol. 25:94-106.

2. Barnes, E. M., and H. S. Goldberg. 1965. The bacteroides of poultry caeca and their relationship with human strains. Ernährungsforschung 10:489-497.

3. Barnes, E. M., and C. S. Impey. 1968. Anaerobic gram negative nonsporing bacteria from the caeca of poultry. J. Appl. Bacteriol. 31:530-541.

4. Barnes, E. M., and C. S. Impey. 1970. The isolation and properties of the predominant anaerobic bacteria in the caeca of chickens and turkeys. Br. Poult. Sci. 11:467-481.

5. Barnes, E. M., and C. S. Impey. 1972. Some properties of the nonsporing anaerobes from poultry caeca. J. Appl. Bacteriol. 35:241-251.

6. Goldberg, H. S., E. M. Barnes, and A. B. Charles. 1964. Unusual Bacteroides-like organism. J. Bacteriol. 87:737-742.

7. Harrison, A. P., Jr, and P. A. Hansen. 1963. Bacteroides hypermegas nov. spec. Antonie van Leeuwenhoek J. Microbiol. Serol. 29:22-28.

8. Holdeman, L. V., and W. E. C. Moore. 1974. New genus, Coprococcus, twelve new species, and emended descriptions of four previously described species of bacteria from human feces. Int. J. Syst. Bacteriol. 24:260-277. 
9. Holdeman, L. V., and W. E. C. Moore. 1974. Genus I. Bacteroides Castellani and Chalmers, 1919, p. 393395. In Buchanan, R. E., and N. E. Gibbons (ed.), Bergey's manual of determinative bacteriology, 8th ed. Williams and Wilkins Co., Baltimore.

10. Holdeman, L. V., and W. E. C. Moore (ed.). 1975. Anaerobe laboratory manual, 3rd ed., p. 101-128. Virginia Polytechnic Institute and State University, Blacksburg, Va.

11. Lapage, S. P., P. H. A. Sneath, E. F. Lessel, V. B. D. Skerman, H. P. R. Seeliger, and W. A. Clark (ed.). 1975. International code of nomenclature of bacteria. American Society for Microbiology, Washington, D.C.

12. Macy, J., I. Probst, and G. Gottschalk. 1975. Evidence for cytochrome involvement in fumarate reduction and adenosine $5^{\prime}$-triphosphate synthesis by Bacte- roides fragilis grown in the presence of hemin. J. Bacteriol. 123:436-442.

13. Mayhew, J. W., A. B. Onderdonk, and S. L. Gorbach. 1975. Effects of time and growth media on short-chain fatty acid production by Bacteroides fragilis. Appl. Microbiol. 29:472-475.

14. Mitsuoka, T., A. Terada, K. Watanabe, and K. Uchida. 1974. Bacteroides multiacidus, a new species from the feces of humans and pigs. Int. J. Syst. Bacteriol. 24:35-41.

15. Moore, W. E. C., and L. V. Holdeman. 1974. Human fecal flora: the normal flora of 20 Japanese-Hawaiians. Appl. Microbiol. 27:961-979.

16. Wilkins, T. D., and T. Thiel. 1973. Modified broth-disk method for testing the antibiotic susceptibility of anaerobic bacteria. Antimicrob. Ag. Chemother. 3:350356. 